\title{
第45回 近畿脳腫瘍病理検討会記録
}

\author{
平成 7 年 2 月 7 日（第 1 ビル・大阪） \\ 会長 西原 毅 \\ （武田総合病院＼cjkstart脳神経外科）
}

\section{転移性脳腫瘍と鑑別を要した前頭葉内腫瘍}

近畿大学医学部 脳神経外科

赤井 文治, 種子田 護

内山 卓也, 片岡 和夫

症例：25歳, 女性

主訴：痘攣

現病歴：11月中旬より左側頭部痛, 嘔氣があった. 平 成 6 年12月 1 日に右上肢の脱力, しびれ感が起こり約 1 分で消失した，同10日には右上肢の㽷攣後意識消失 (2 -3 分）を伴った.

即往歴・家族歴 : 子宮腺筋症

神経学的所見 : 右半身に軽度の不全麻疸

画像診断：CT 上左前頭葉皮質表面に不均一に増強さ れる多胞性の腫瘍 (径 $3 \mathrm{~cm}$ ) が認められ, MRIにても 同様の所見であるが, 脳室との関係は認められない (Fig. 1).

手術所見：腫瘍は脳表に一部露出しており, 周囲皮質 とは境界が比較的明瞭であった. 軟らかく, 易出血性で あり腫瘍内出血を認めた．多数の蘘胞も認めた。

組織所見：間質の少ない部分と, 出血周囲の間質に富 む組織があるが, 全体に管腔形成, 乳頭状増殖を思わせ る構造がみられた。ここの細胞は胞体が長く, 異形性, 多形性に富む核に偏在が見られた。血管腔に胞体を伸ば した perivascular rossete を思わせる. 一層に配列した 部分では管腔面に核が偏在し，纎毛の形成が認められた

(Fig. 2). 出血, 壊死, 核分裂像を多数認めた. 病理医 よりは腺癌, 転移性脳腫瘍の診断であった。

Comments：腺癌とすると卵巣由来が考えられたが, 胞体が極めて長いと思われた．後日の免疫染色で GFAP 陽性細胞を多く認めた. malignant ependymoma を考え たが，脈絡叢の papillary carcinoma との意見が有り， 上皮性の要素を検討するため EMA 等の染色による検討 をすることとした.電子顕微鏡下にも検討の予定である.

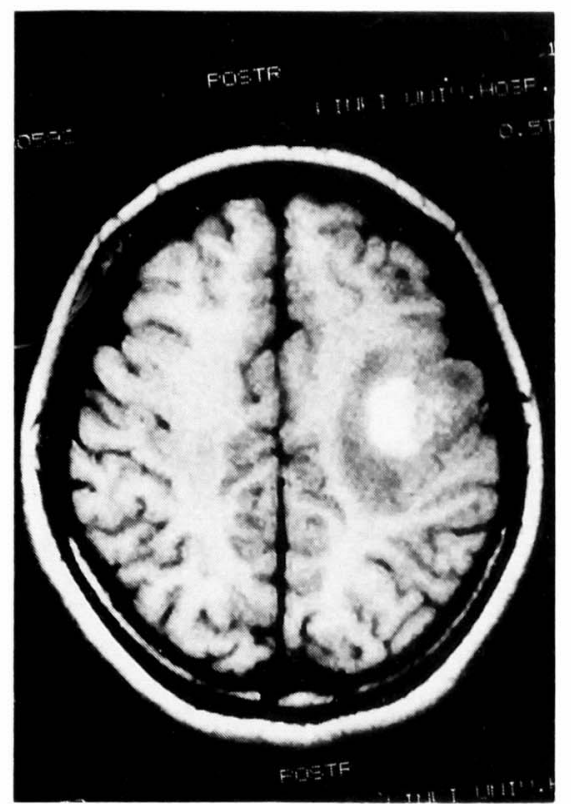

Fig. 1 Sagital view of Gd-enhanced MRI

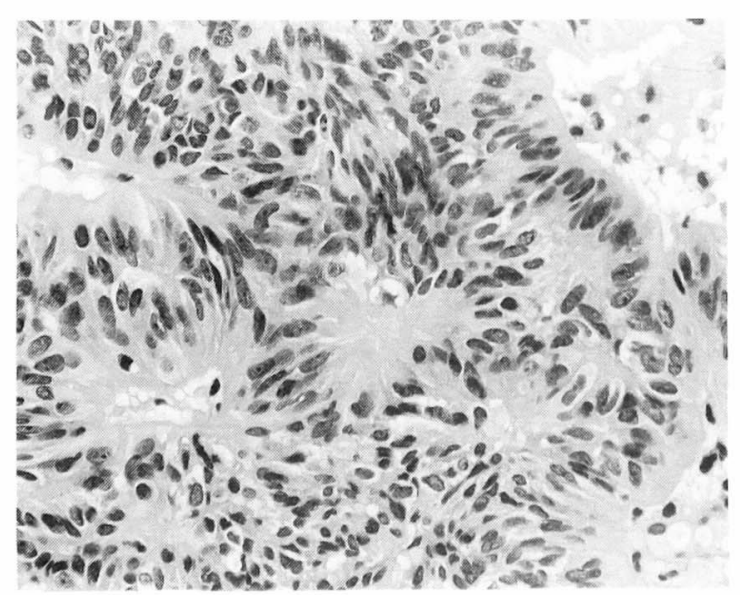

Fig. 2 Perivascular rosette or papillary growth. $\mathrm{H} \& \mathrm{E} \times 200$ 
巨大な olfactory groove meningioma $の 一$ 症例

医仁会武田総合病院 脳神経外科

$\begin{array}{lll}\text { 西原 毅, 梶田 健 } \\ \text { 西浦 厦, 半田 肇 }\end{array}$

症例：75歳, 男性

主訴：異常行動，失見当識

現病歴：1994年11月よりよくどもる様になり，浣腸を くわえたり，異常行動が目立つようになった，某院にて MRI で脳腫瘍を指摘され，当院へ紹介された。

既往症：1992年 4 月, 胃癌のため内視鏡的摘出術をう ける. 最近，同部位よりポリープが確認されている。そ の組織型は不明である.

神経学的所見: 失見当識, 軽度の意識障害. 右上下肢 の筋力低下, 歩行障害.

頭部単純写：特記すべき所見なし.

MRI 所見：前頭蓋底に接して上方へ 2 つコブ状に 前頭葉を押し上げる形の直径 $7-8 \mathrm{~cm}$ の腫瘍で, 副鼻腔 への腫瘍の浸潤は認めなかった。また T1WI で iso, T2WI で high intensity で, 中心部に一部 low intensity の部分をともなうが，ほほ均一に造影効果を受けた。境 界は鮮明であるが, perifocal edemaは顕著であった。

脳血管写：主に前大脳動脈より淡い tumor stain を認 めた。

経過：入院後, 約 2 週間のステロイド多量療法で精神 症状は著明に改善した。

手術：両側前頭一左側頭開頭にて腫瘍を生検したとこ ろ, meningioma あるいは Schwannoma と報告された. 腫瘍は被膜におおわれ，脳表との剝離は全周にわたり容 易であった，灰白色の腫瘍で弾性ゴム様の硬さがあり一 部を除いて unsuckable であった. 硬膜より多くの血管 が入っていたが, 硬膜に浸潤はなく, olfactory groove にわずかに付着するのみであった，肉眼的には，嗅神経 より出た腫瘍と思われたが, 篩骨への浸潤, 骨の破壊な ど認めなかった。

光顕所見：大部分は変性しヒアリン化した基質よりな り, fibrous pattern と細胞が密の部位では whorl formation 様所見を呈したが，核が palisading 様に配列をして
いる部位が認められた。 また，クロマチンの少ない淡く 染色される丸みのある小型の核をもっていた. 免疫染色 S-100, NES は negative で vimentin は基質の多い部位 で positive となった. 以上より meningotheliomatous meningioma と診断された.

Comments：HE 染色で核が palisading 様所見を呈した 部分を認めたが, Schwannomaの palisadingでは reticulin fiberも格子状に配列しているのが特徵である. Meningioma のパターンは palisading 様に見えても reticulin fiber がバラバラであることで鑑別が容易である.

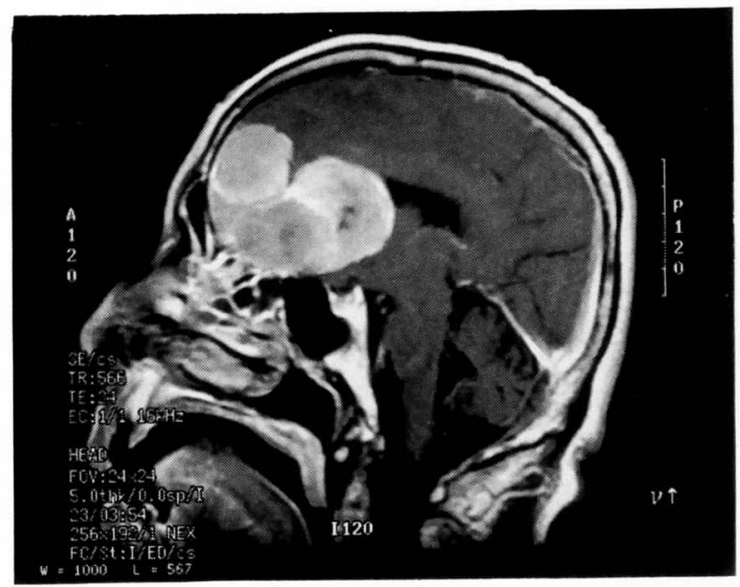

Fig. 1 Preoperative MRI with Gd-enhancement.

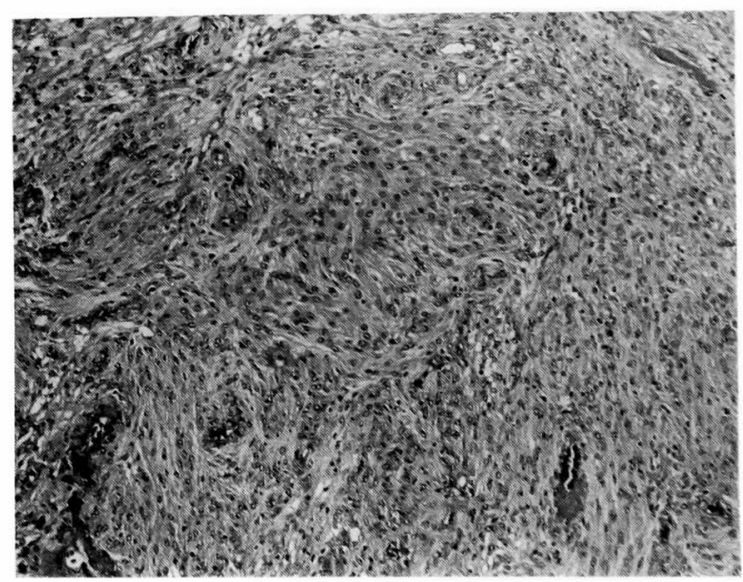

Fig. 2 HE stain 